\title{
Expanding the Role of Philippine Languages in the Legal System: The Dim Prospects
}

\author{
Isabel Pefianco Martin
}

\begin{abstract}
This article considers the prospect of expanding the role of the national language, as well as other Philippine languages, in the legal system. While Tagalog-based Filipino, which is the national language according to the 1987 Constitution, is used extensively alongside English in schools, the national language has made few inroads into the legal system. Very little legislation has been translated into Filipino. Filipino-English code-switching has been observed in courtrooms, but English alone is used for records. In recent years, however, there have been signs of a more favorable attitude in the legal profession toward bilingualism. Since 2007, certain criminal courts in the Tagalog stronghold of Bulacan have been conducting cases in the national language, with English being retained for civil cases. So far the experiment has had a mixed reception, with some courtroom participants arguing that Filipino brings greater transparency and others claiming that it reduces efficiency. By weighing the preferences of legal professionals against the needs of defendants, witnesses and litigators, I consider the possibility of extending the Bulacan experiment to the rest of the Philippines. In this article, I also explore the question of introducing regional languages into the legal domain.
\end{abstract}

KEYWORDS: Language and law, Philippine languages, Philippine legal system

\section{INTRODUCTION}

At a hearing on a homicide case, Regional Trial Court (RTC) Presiding Judge Ronaldo Martin prepared to dismiss the case because neither witnesses nor representatives of the victim had been attending the sessions. 
The case had lagged for almost four years. But just before Judge Martin announced his decision, he asked one more question, this time using the Filipino language: "Sino sa inyo ang nakakakilala sa biktima? (Is there someone in this room who knows the victim?)" An elderly woman raised her hand. Judge Martin explained to her the situation and, recognizing that the woman had frequented his courtroom, asked why she had not been participating in the sessions. The woman replied, "Hindi po ako marunong ng English. (I do not know English)" (Martin).

The anecdote above is only one among countless court proceedings in the Philippines that shows the English language driving a wedge between two distinct social classes-the minority elite and the majority Filipino masses. Such a condition persists at the expense of a speedy and fair dispensation of justice. This reality was recognized by the Supreme Court (SC) of the Philippines when, in 2006, at the National Forum on Liberty and Prosperity, it was "resolved, among others, to adapt the language of the law to that of the common people to enhance their access to justice" (Zuniga). The Supreme Court then created the Committee on Linguistic Concerns, ${ }^{1}$ which was an admission of the need to "break the language barrier and give full access to justice to all sectors..." ("Landmark SC Decisions").

The so-called language barrier in the Philippine legal system is symptomatic of deeper issues of language and power that have beset other sectors such as education, trade and industry. But while the education sector, through the newly implemented MTBMLE ${ }^{2}$ policy of the Department of Education (Memo. No. 74), has begun to seriously address the marginalization brought about by the English language, the legal system remains a stronghold of the language. Laws and court decisions are largely written in English and these are rarely translated into Filipino. And while code-switching may sometimes be observed in courtrooms, English alone is used for records.

\section{PHILIPPINE LANGUAGE POLICY}

The 2000 Philippine Census reports that 65 million out of 76 million Filipinos are able to speak the national language as a first or second lan-

${ }^{1}$ The full name is Committee on Linguistic Concerns to Translate Landmark Supreme Court Decisions into Filipino and Other Major Philippine Dialects.

${ }^{2}$ The Mother-Tongue Based Multilingual Education Policy for Philippine Basic Education (MTBMLE) began implementation in June 2010. 
guage (Nolasco). Despite this, the Filipino language has made few inroads in the legal system. To be sure, the language policy of the country is not to be blamed. ${ }^{3}$ In fact, the 1987 Philippine Constitution explicitly communicates the government's bias for Filipino by mandating that "For the purpose of communication and instruction, the official languages of the Philippines are Filipino and, until otherwise provided by law, English" (art. 14, sec. 7). Such a bias for the national language was unthinkable before this time.

The Philippines is a country of 175 individual languages (Lewis). Deciding which among these languages should become the national language would naturally result in vehement objections as well as heated arguments and debates, especially from members of the five biggest languages: Tagalog, Cebuano, Ilocano, Hiligaynon, and Bicol. In the end, the government decided on Tagalog as the base of the Filipino language. But this choice was not without controversies.

The identification of a national language did not happen when the first Philippine Constitution, also known as the Malolos Constitution, was written 1899. This constitution made no reference to an official language, but simply states that:

The use of languages spoken in the Philippines shall be optional. Their use cannot be regulated except by virtue of law, and solely for acts of public authority and in the courts. For these acts the Spanish language may be used in the meantime. (art. 93)

It was in 1935, during the period of the Philippine Commonwealth, ${ }^{4}$ that the government first made explicit its desire to adopt a national language, while maintaining Spanish and introducing English as official languages. The Philippine Constitution of 1935 mandated that "Congress shall take steps toward the development and adoption of a common national language based on one of the existing native languages" (art. 14, sec. 3). However, the choice of one native language was, as linguist Andrew Gonzalez describes, "fraught with problems that only time can solve..." ("Language and Nationalism" 233).

The Marcos Constitution of 1973 finally named a national language when it directed the National Assembly to "take steps towards the develop-

${ }^{3}$ In arguing that there is a lack of constitutional continuity in the Philippines, Rappa and Wee present the "legal benchmarks of language policy" through a detailed discussion of the language provisions of four Philippine constitutions. (Rappa and Wee 66)

${ }^{4}$ This was the period when the Philippines was a colony of the United States. 
Isabel Pefianco Martin, "Expanding the Role of Philippine Languages in the Legal System"

ment and formal adoption of a common national language to be known as Filipino" (art. 15, sec. 3). That same article referred to English and Pilipino as official languages. Rappa and Wee describe this period in the history of Philippine language policy as presenting

a clear legal distinction ... between the linguistic goal or linguistic ideal of the nation-state and the transitory linguistic form of the official language. Therefore, under the Marcos Constitution of 1973, "Filipino" was designated the ideal linguistic form while Pilipino was decreed as the transitory official language of the nation-state. No other mention of "language" is found in the 1973 Marcos Constitution. (68)

But for Gonzalez, the designation of Filipino as a language to be formed from existing Philippine languages creates a "legal fiction" (229). He adds that

if one were to take the mandate seriously as a linguist, what we would have ended up with was a Philippine Esperanto, a language no one spoke natively and the chances for the use of which would be almost nil. ("Language and Nationalism" 229)

This legal fiction from the 1970s did not receive much opposition when the language question was revived with the formulation of the post-Marcos 1987 Constitution. Soon after toppling the Marcos dictatorship in 1986, President Corazon Aquino fast-tracked the creation of a new Constitution, which was unlike its 1973 predecessor in that it categorically states that Filipino is the national language of the Philippines. Art. 14, sec. 6 goes on to mandate the following:

As it (Filipino) evolves, it shall be further developed and enriched on the basis of existing Philippine and other languages. Subject to provisions of law as the Congress may deem appropriate, the Government shall take steps to initiate and sustain the use of Filipino as a medium of official communication and as language of instruction in the educational system.

Gonzalez, who had always been in the middle of language debates in the country, found the identification of a national language by the new Aquino government to be surprisingly smooth and uncontroversial. Gonzalez writes:

After the ratification of the Constitution in 1987, my mind was at rest. Selection was no longer a problem; neither was propagation a problem 
since Tagalog-based Pilipino had been spreading by leaps and bounds... ("Language and Nationalism" 230)

One year later, President Aquino, in another attempt to promote the national language, issued Executive Order (E.O.) No. 335, which reminded government units that

the intensified use of Filipino language in official transactions, communications and correspondence in government offices will hasten greater understanding and appreciation among the people of government programs, projects and activities throughout the country, thereby serving as an instrument of unity and peace for national progress.

With this premise, E.O. 335 enjoined all government units to "take steps to enhance the use of Filipino in all official communications, transactions and correspondence in their respective offices."

The Executive Order was not received well by the public. Linguist Bonifacio Sibayan reported that the order was "met with hostility in a number of native non-Tagalog-speaking places and ignored by the bureaucracy" (Sibayan 1991). Gonzalez wrote that this negative reaction to E.O. 335, which came as another surprise considering the positive reception to the language provision of the 1987 Constitution, signaled an "awareness that Filipino is not sufficiently developed and cultivated as a language of scholarly discourse..." ("Language and Nationalism" 232).

Indeed, such perception of the national language as not fully developed is not unfounded. The language may have widespread use as a national lingua franca, but it remains in the margins of Philippine society. Filipino has not yet made significant headway in the controlling domains of legislation and governance, science and technology, business and economics, and higher education (Gonzalez, "Incongruity" 230-231; Sibayan 240-241).

One important domain that continues to resist the use of the national language is the legal system which Gonzalez described as having a "divergence in the language of law, predominantly English, and the language of court proceedings, English and Filipino" (Gonzalez, "Incongruity" 229). He attributes this incongruity to a "sociolinguistic situation of a post-colonial independent country that is in the process of developing its national language" ("Incongruity" 229). 
Isabel Pefianco Martin, "Expanding the Role of Philippine Languages in the Legal System"

\section{THE BULACAN PILOT PROJECT}

A Public Opinion Survey on the Courts (POSC) held in 2003 showed that $46 \%$ of the respondents reported their difficulties in understanding English during legal proceedings, while $40 \%$ claimed that even when judges and lawyers use the respondents' language, they still could not understand what these judges and lawyers say in court (Mangahas). The results of this survey point to serious ailments that continue to plague the Philippine legal system. The judicial system has always been perceived to be anti-poor. And these weaknesses, which involve more than just language issues, are further reinforced by the continued dominance of a language that makes justice elusive to the needy. One may argue that the language policy of the Philippine judiciary, which is determined by what the 1987 Constitution prescribes, allows for two languages-English and Filipino. However, in practice, it is English that clearly dominates the system. English is in fact the default language of Philippine court proceedings.

In the Rules of Court employed by the Supreme Court, only two provisions refer to language concerns: Rule 116 on Arraignment and Plea allows for the use of the language known to the accused, while Rule 120 on Judgment prescribes that a judgment "must be written in the [italics mine] official language, personally and directly prepared by the judge and signed by him..." The rule implies that there is only one official language-English.

The same premise seems to be made by Retired Judge Cezar C. Peralejo and Chief Public Attorney Persida Rueda-Acosta when they appealed to the Supreme Court in 2005 for a "policy decision to authorize the use of 'Filipino' in our courts of justice without eliminating English as the official language of the courts" (Request for a Policy Decision). Like Rule 120, this appeal also implies that English is the only official language of the courts. In addition, the appeal may also signal a growing perception that the language barrier in the Philippine legal system continues to push the masses to the margins.

In 2007, through the efforts of the Supreme Court's Committee on Linguistic Concerns, three RTCs in the Tagalog stronghold of Bulacan were directed to conduct court proceedings in the Filipino language. The program had two objectives: to promote the national language and to expedite the handling of legal cases. The latter objective was to be achieved by eliminating translations between English and Filipino. It was assumed that court proceedings conducted in Filipino would ensure full understanding among all participants in a case (Reyes, "Three Bulacan Courts"; Ortiz). 
In the first stage of implementation of the project, stenographers were trained to take notes in Ikilat, the Filipino stenography. All new cases were heard, recorded and documented in Filipino. The Committee's plan was to make the three RTC branches as model courts for others in the Tagalog-speaking regions to imitate (Reyes, "Three Bulacan Courts"; Ortiz). Judge Ma. Resureccion Ramos Buhat, presiding judge of one of the three branches in the pilot project, observed that there is "more silence in my court because everybody understands what is going on and everybody listens" (Reyes, "Bulacan Uses"). Buhat reported that with the use of Filipino in her courtroom, time spent on trials had significantly shortened because litigants did not anymore require translations (Reyes, "Bulacan Uses").

The move to use Filipino in court proceedings was met with varied reactions, among them, from non-Tagalog speakers. In his letter to the editor, Stephen Monsanto argued that Tagalog-based Filipino is not necessarily understandable to Filipinos in the Visayas and Mindanao regions. He writes in "But Tagalog is Greek to Visayas, Mindanao":

To a great many people there, Tagalog 5 is as Greek as English is to them. If the goal is to make them also understand judicial proceedings, the courts there should also use the languages spoken in those areas... (however) Such as cacophony of court records in different dialects would be one insurmountable problem on appeal even if we concede that the justices of the Supreme Court in Manila are fast learners and become polyglots overnight.

Monsanto is of course arguing for maintaining English. Public opinion researcher Mahar Mangahas, also in reaction to the Bulacan Pilot Project, reminded the Supreme Court about the 2003/4 Social Weather Station survey which reported that $76 \%$ of the RTC-and lower-level-court-judges did not agree to the use of local languages in court proceedings (Mangahas). Thus, Mangahas argues, "The activist Chief Justice faces a strong bias among his own colleagues."

Despite these negative reactions, the Supreme Court persisted in its attempts at breaking the language barrier. Shortly after the pilot stage of the project, personnel from 15 other courts in Bulacan (which included both regional and municipal trial courts) underwent training in order to implement the use of Filipino in their courtrooms. After some time,

${ }^{5}$ As in many Filipinos from the Visayas and Mindanao, Monsanto uses the term "Tagalog" to refer to "Filipino," the national language. 
however, the courts either lost interest in the project, or found that the directive was just too difficult to implement. The most affected seemed to be the stenographers who could not adjust to taking notes in Ikilat. It was also observed that some lawyers were not used to communicating legal concepts in Filipino (Buhat).

In January 2010, the Bulacan judges and stenographers appealed to the Supreme Court to reconsider its directive to use Filipino in court proceedings. The result of this move is the Supreme Court Administrative Circular No. 16-2010, issued to all the Bulacan courts, which declared the following:

In view of the difficulties encountered in the use of Filipino in court proceedings manifested by the Presiding Judges and the court stenographers ... as expressed in their letters dated January 12, 2010 and January 7, 2010, to the Chancellor of PHILJA, the use of the national language therein shall be optional and on a per case basis.

As of this writing, only Branch 80 of Judge Buhat maintains the practice of using the national language. In Judge Buhat's courtroom, Filipino is used in all levels of transactions, from the first pleading filed and all pleadings thereafter, to oral arguments, to transcription of stenographic notes, to decisions on cases. Since 2007, all documents and records (except the Warrant of Arrest ${ }^{6}$ ) in Branch 80 had already been translated to and/or written in Filipino. This practice continues with legal jargon (having no Filipino equivalents) maintained in English. Judge Buhat believes that it was relatively easy for her branch to translate all the relevant laws because she held a special court that focused only on drugs. However, for Judge Buhat, the practice of using the national language in her court proceedings was also a matter of political will. She firmly believes that the benefits of the practice far outweigh whatever difficulties arose (Buhat).

\section{PROSPECTS FOR FILIPINO AND OTHER PHILIPPINE LANGUAGES}

When asked if the Supreme Court had plans of extending the Bulacan Pilot Project to other courts in the Tagalog-speaking regions, Maria Victoria Guerra of the SC's Public Information Office replied in a personal

${ }^{6} J u d g e$ Buhat reported in an interview that it was difficult to translate the Arrest Warrant because the document contains legal jargon. 
interview that there was no such plan. The fact of only one RTC branch in Bulacan persisting in the practice, out of the 15 that attempted to use Filipino in court proceedings, already signals dim prospects for the national language to thrive in the legal system. This may be attributed to what Gonzalez describes as the "relatively uncultivated state" of Filipino vis-à-vis English ("Language and Nationalism" 237). Filipino may have already become a national lingua franca with widespread use in media, commercial transactions, and interpersonal communication, but the language has not yet fully penetrated the controlling domains of law and legislation, government and administration, science and technology.

Sibayan, in arguing that Filipino is not yet fully intellectualized, uses Ferguson's (Sibayan 244) criterion of intertranslatability as a condition for the intellectualization of a language. In the case of Filipino, translation is "a very difficult and time-consuming process because Filipino still has to develop the vocabulary, the terminology, thematizations, and the registers and discourse types for practically all intellectual disciplines" (Sibayan 245). In addition, the intertranslatability feature of the Filipino language is of the one-way type. Texts in English are translated into Filipino, but it is uncommon for texts in Filipino to be translated into English. Thus, the intellectualization process has become dependent on another language, a more intellectualized language that is English (Sibayan 244).

If prospects are dim for expanding the use of the national language in the legal system, what then does the future hold for other Philippine languages such as Cebuano, Hiligaynon, Ilocano, and Bikol? Lawyers who have been practicing in the Visayas region, where Cebuano and Hiligaynon are spoken, do not see the use of these languages as feasible in court proceedings. Of 15 Visayas-based lawyers interviewed, ten did not believe that their native languages would thrive in the legal system for the following reasons:

- "Filipino language may be okay but local dialects can never be used as rulings of the court are subject to appeal and there is no assurance that the appellate court will understand the local dialect" (Untaran).

- "It (using Philippine languages) is a welcome proposal but it needs extensive study and preparation considering that there are legal terminologies which have no equivalent in Tagalog words and vice-versa" (Alcantara). 
Isabel Pefianco Martin, "Expanding the Role of Philippine Languages in the Legal System"

- "(Using Philippine languages is) [i]nteresting but quite difficult since the language used in law schools is English. The textbooks are also in English" (Capacio-Plameras).

- "Such prospect (of using Philippine languages) is greatly debilitated by the fact that most judges are assigned outside their hometown or province, and their places of assignment most often are of a different dialect. Moreover, lawyers are also handling cases in several provinces with varying dialects" (Espera).

- "It (using Philippine languages) will create confusion because our laws and jurisprudence are all written in English" (Huele).

- "It would be right to use Filipino. However, if any other dialect or language would be used, it would be very difficult for most lawyers" (Alicando).

- "It (using Philippine languages) is not feasible because of our diverse languages. It would entail all lawyers to learn all existing languages and would necessitate translations of pleadings and court orders or resolutions to one common language which is not beneficial to both the court and its clientele" (Abelgos-Espera).

- "I have no problem with that (using Philippine languages). In fact, doing so would put on record the true meaning of the Filipino (or other Philippine language) term being used. However, there is a need to train the court stenographers to write Filipino or other Philippine language in "shorthand"' (De la Cruz).

- "English should still be the language of choice in court proceedings and must play an important role in the Philippine legal system" (Rivero).

Indeed, English is the language of choice in the Philippine judiciary. Court proceedings continue to depend on this language-a language that is not entirely accessible to the Filipino masses, especially in its form as a legal register. And because English is not fully understood by the masses, the 
courts have to rely on translations, which are likewise not totally dependable in presenting accurate accounts of a case.

The continued dominance of English in the Philippine legal system, as well as dim prospects for using the national language in court proceedings, does not necessarily mean that there is no place at all for Philippine languages in the justice system. There exists another system, described by Jennifer Franco (214) as a "quasi-state regulated" system, that is more transparent in its dealings with the masses, especially where languages are concerned. This is the system of barangay ${ }^{7}$ justice provided for in Republic Act 7160, also known as the Local Government Code of the Philippines.

The barangay is defined in RA 7160 as the basic political unit responsible for planning and implementing government policies, plans, and projects. Through the punong barangay (head of the barangay, also known as barangay captain), it is also empowered to oversee the settlement of disputes among residents of a community. It is generally believed that such disputes end amicably with cases rarely elevating to higher, more formal courts. Anthropologist Michael Tan narrates how, in barangay justice negotiations, "language sets the stage." He writes:

Being able to speak, even occasionally curse-in Filipino or Cebuano or Ilocano-allows people to bring out important information to argue a case. Speaking in Filipino, the barangay captain comes through as firm, yet understanding. I've seen a tiny woman barangay captain restrain huge bullies, calm fiery wives, admonish haughty mistresses with two words: "Makinig ka." She wouldn't have been as effective if she said, "Listen." (Tan)

Thus, what is evident in the Philippine legal system, is what Franco describes as a "two-tiered multilingual system of state law," which

features both (1) the more specialized, formal technical-legal English (formerly Spanish) of a colonial-bred judiciary on the one hand and (2) the more informal vernacular (expressed in different local languages and dialects) of a state-powered village justice system on the other. (191)

However, the relative informality and accessibility offered by the barangay justice system remains limited in its capacity to address more serious grievances and crimes. Only minor cases of disputes between members of a community may be brought to the barangay level. For more serious

${ }^{7}$ The term barangay may be loosely translated into "village." 
Isabel Pefianco Martin, "Expanding the Role of Philippine Languages in the Legal System"

cases, both victims and the accused will require the assistance of higher authorities, such as police officers, lawyers, prosecutors, and judges. In such situations, the law, largely written in English, will have to be interpreted before a case is resolved. In the end, the Filipino masses must depend on this legal system that continues to confound them, while frustrating attempts to gain genuine redress of grievances and uphold people's rights. Thus, until such time when the language of the Philippine legal system becomes truly transparent and genuinely available to all Filipinos, justice in the Philippines will remain elitist and elusive.

\section{WORKS CITED}

Abelgos-Espera, Ruby. Personal Interview. 20 May 2011.

Alcantara, Antonio. Personal Interview. 20 May 2011.

Alicando, Celso Dan. Personal Interview. 20 May 2011.

Buhat, Ma. Resureccion Ramos. Personal Interview. 10 May 2011.

Capacio-Plameras, Jenny Mae. Personal Interview. 20 May 2011.

De la Cruz, Paul Milben. Personal Interview. 20 May 2011.

Espera, John Mark. Personal Interview. 20 May 2011.

Ferguson, Charles A. "Language Development." Language Problems of Developing Nations.

Ed. Joshua A. Fishman, Charles A. Ferguson, and Jyotirindra Das Gupta. New

York: Wiley, 1968. 27-35. Print.

Franco, Jennifer C. "Balimbing Justice: The Many Languages of Law in the Rural

Philippines." (Re)Making Society: The Politics of Language, Discourse, and Identity in

the Philippines. Ed. T. Ruanni Tupas. Quezon City: U of the Philippines P, 2007. 189-221. Print.

Gonzalez, Andrew. "Incongruity between the Language of Law and the Language of Court Proceedings: The Philippine Experience." Language and Communication 16.3 (1996): 229-34. Print.

---. "Language and Nationalism in the Philippines: An Update (1990)." Readings in Philippine Sociolinguistics. Ed. Ma. Lourdes S. Bautista. Manila: DLSU P, 1996. 228-39. Print.

Guerra, Maria Victoria G. Personal Interview. 13 May 2011.

Huele, Ricardo. Personal Interview. 20 May 2011.

Lewis, M. Paul, ed. Ethnologue: Languages of the World. $16^{\text {th }}$ ed. Dallas: SIL International, 2009. Web. 9 May 2011.

Mangahas, Mahar. "Social Climate: Survey on Access to Court Justice." Inquirer.net 5 July 2008. Web. 4 May 2011.

Martin, Ronaldo. Personal Interview. 19 May 2011.

Monsanto, Stephen L. "But Tagalog is Greek in Visayas, Mindanao." Inquirer.net 5 Oct. 2009. Web. 4 May 2011. 
Nolasco, Ricardo D. "The Prospects of Multilingual Education and Literacy in the Philippines." The 2nd International Conference on Language Development, Language Revitalization, and Multilingual Education in Ethnolinguistic Communities, Bangkok. 1-3 July 2008. Web. 8 February 2012.

Ortiz, Margaux. "SC: Use of Filipino Language in Courts Positive." Inquirer.net 1 July 2008. Web. 4 May 2011.

People of the Phils. v. Mechor Estomaca y Garque. G.R. Nos. 117485-86. Supreme Ct. of the Phils. 1996. Web. 4 May 2011.

Rappa, Antonio L. and Lionel Wee. Language Policy and Modernity in Southeast Asia: Malaysia, the Philippines, Singapore, and Thailand. New York: Springer, 2006. Print.

Rep. of the Philippines. Dept. of Education. Memo. No. 74: Institutionalizing Mother Tongue Based Multilingual Education. 2009.

---. Exec. Order No. 335: Enjoining All Departments/Bureaus/Offices/ Instrumentalities of the Government to Take Such Steps as Are Necessary for the Purpose of Using Filipino Language in Official Transactions, Communications and Correspondence. 1988.

---. Local Government Code of 1991. The LawPhil Project of Arellano Law Foundation. Web. 12 December 2011.

Request for a Policy Decision Regarding the Use of Filipino in Our Courts of Justice. A.M. No. 05-2-08-SC. Supreme Ct. of the Phils. 29 March 2005. Web. 4 May 2011.

Reyes, Carmela. "Bulacan Uses Filipino in Court Trials." Inquirer.net 20 August 2009. Web. 4 May 2011.

--_. "Courts Urged to Use Filipino in Proceedings." Inquirer.net 31 August 2007. Web. 4 May 2011.

---. "Three Bulacan Courts to Use Filipino in Judicial Procedings." Inquirer.net 22 August 2007. Web. 4 May 2011.

Rivero, BG. Personal Interview. 20 May 2011.

Sibayan, Bonifacio. "The Intellectualization of Filipino (1991)." Readings in Philippine Sociolinguistics. Ed. Ma. Lourdes S. Bautista. Manila: DLSU P, 1996. 240-253. Print.

Supreme Ct. of the Phils. Administrative Circular No. 16-2010: Use of Filipino in Court Proceedings. 2010. Web. 4 May 2011.

---. "Landmark SC Decisions Soon in Filipino, RP Dialects." CourtNews 2006. Web. 4 May 2011.

---. Rules of Court. 2000. Web. 23 May 2011.

Tan, Michael. "Language and the Law." Inquirer.net 25 August 2006. Web. 5 May 2011.

Untaran, Silvestre, II. Personal Interview. 20 May 2011.

Zuñiga, Genevieve B. "Court Watch: Committee on Linguistic Concerns Created." Benchmark Online September 2006. Web. 4 May 2011. 
Isabel Pefianco Martin, "Expanding the Role of Philippine Languages in the Legal System"

Isabel Pefianco Martin is Associate Professor at the Department of English, Ateneo de Manila University. She is also Acting Executive Director of the Philippine Social Science Council (PSSC). Prior to this post, she served as president of the Linguistic Society of the Philippines, chair of the Department of English, commissioner of the Komisyon sa Wikang Filipino (Commission on the Filipino Language), and research coordinator of the Ateneo School of Humanities. Her research interests include descriptions of English, World Englishes, Philippine English, and languages in education. 